\title{
Mewburn: London silversmiths
}

\author{
Ian G. Macdonald
}

Abstract: Mewburn is a significant name in silversmithing, yet almost nothing has been written about those of them involved in the craft or their history. That leaves the question: who exactly were the silversmithing Mewburns and what were their origins

Received: 03 February 2017 Accepted: 01 March 2017

Additional information is available at the end of the article.

KEYWORDS: Mewburn; genealogy; Goldsmiths' Company; goldsmith; silversmith; Freeman; guild; migration; Nonconformist and the ultimate fate of their line? Genealogical techniques have been used to fill the structural gaps and flesh out an understanding of the three generations in which there were members of the Goldsmiths' Company, and to trace their fortunes in the eighteenth and nineteenth centuries, and the eventual end of the line in the early twentieth century. The article also shows how records from the Goldsmiths' Company can provide insights into the lives of nineteenth-century craftsmen - individuals and their families. London birth, marriage and death records and wills have enabled a sound family tree to be developed, while property and tax records have provided locational data. Migrations have been traced and Australian records used to document the final decline of the silversmiths. Some speculation on the earlier origins of the line is offered.

\section{Introduction}

Mewburns have lived in London since at least the beginning of the seventeenth century, though the name is predominantly associated with North Yorkshire and County Durham. What took them there in the first place and where the first ones came from is uncertain, but they may all have been closely related given the rarity of the name. The majority in London belonged to one family and within that family there were three generations of silversmiths - all Freemen of the Goldsmiths' Company and some also Freemen of the City of London. Two of them, John (1762-1830) and his son Barak (1800-1869), were distinguished makers whose work still regularly appears at auction. John was sufficiently important to have risen to become a Liveryman of the Goldsmiths' Company, while his first son, Henry John (1796-1836), Barak's elder brother, was a weigher at the Assay Office.*

\section{The first generation}

John Mewburn was baptised on the 6th of February 1762 at St Andrew, Holborn, an area near Hatton Garden. ${ }^{1}$ He was the son of John and Rebecca Meaburn [sic] of Purpool Lane (today called Portpool Lane, off Gray's Inn Road) and was the youngest of their four children. Since he is known to have practised as a silversmith in London, he had to have been a guild member so records were explored at the private library of the Goldsmiths' Company in Goldsmiths' Hall on Foster Lane in London. ${ }^{2}$ The Goldsmiths' Company records can be of great value to the genealogist, providing information about apprenticeship, subsequent history of practice (in the Black Book) and even pensions and other social support, and often naming parents and sometimes other family members.

John appears in the Black Book of the Goldsmiths' Company as:

Mewburn John; father John; Master Jn Crouch $\quad$ Vol 8, page 302; 1777 Bound in name of Nubron Freedom 4 Jul 1792; Livery June 1811, Goswell St; died 27 Jan $1830 .^{3}$

and appears also in their Apprentice Book where the entry reads:

*An earlier draft of part of this article appeared for a time on a trial website (http://www.mewburnandmeaburn.com), but has subsequently been removed. 


\begin{abstract}
1777 , Febry $5^{\text {th }}$
Be it Remembered that I John Nubron Son of John Nubron late

of Fore Street London Mariner deceased

do put myself Apprentice to John Crouch of Giltspur Street London

Silversmith _ _ _ Citizen and Goldsmith of London to learn his Arts of a

Silversmith _ _ _ for the Term of Seven Years from this Day
\end{abstract}

John Nubron. ${ }^{4}$

Much of this is repeated by Grimwade, ${ }^{5}$ in his compendium of London silversmiths, who describes him as:

Son of John Nubron of Fore Street ${ }^{6}$ London, mariner deceased, apprenticed as John Nubron (? through some deafness of the clerk) to John Crouch 5 February 1777. Free 4 July 1792. First mark entered as plateworker, 2 October 1793.

Address: Hare Court, Aldersgate Street. Moved to Abingdon Row, Goswell Road, undated. Livery, June 1811. Second mark, 24 March 1823. Died 27 January 1830. Heal records him as Mewburn or Newburn (cf Nubron, Above), goldsmith, Hare Court, 1793-6.

It seems to have taken some time for him to be made free, according to the Black Book, and there is no entry for the event in the Freedom Book. ${ }^{7}$ John registered marks twice with the Goldsmiths' Company:

John Mewburn, Plate Worker, Hare Court

Oct 291793

Aldersgate St

Removed Abingdon Row, Goswell Road

March 241823

In 1793, as shown in Figure 1, his mark consisted of a coronet with five points each topped with a silver ball, over the initials IM (a Latinised version of his own). Two of his marks from around $1796-1797$ are illustrated in London Goldsmiths ${ }^{8}$ and others by Ciceri. ${ }^{9}$

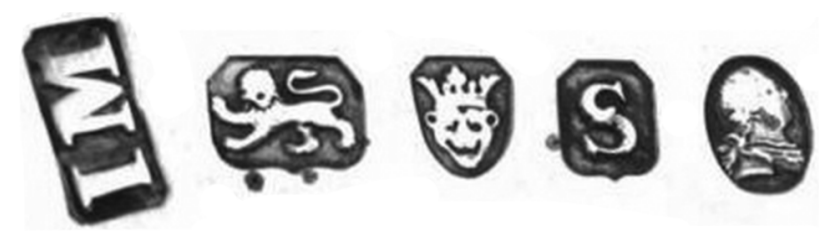

Figure 1. John Mewburn marks (with permission from Giovanni Ciceri).

John's notable contribution to the craft was recognised when he was created a Liveryman of the Goldsmiths' Company in June 1811 (though there is no formal record of that event outside the Black Book). From then he was, and continued to be, noted in the List of the Wardens, Assistants and Livery of the Goldsmiths' Company up until 1829. ${ }^{10}$

The Company has records of six apprentices taken on by John Mewburn between 1795 and 1808:

- John Death; 7 Jan 1795. Vol. 9, p. 307. £5 from the Protestant Dissenters School, St Bartholomew Close, West Smithfield. John at Hare Court, Aldersgate St.

- Thomas Paine Dexter; 1 Jun 1796. Vol. 9, p. 332. £5 from the Protestant Dissenters' School, St Bartholomew Close, West Smithfield. John at Hare Court, Aldersgate St.

- Edward Edwards; 7 Nov 1797. Vol. 9, p. 352. Son of a silversmith. John at Hare Court, Aldersgate St.

- Thomas Layton; 3 Mar 1801. Vol. 9, p. 411. £5 5s from the Goldsmiths' Company. John at Hare Court, Aldersgate St.

- Jos Eldad Webb; 5 Dec 1804. Vol. 10, p. 41. Son of a watchmaker. John at Aldersgate St.

- Philip Williams; 3 Aug 1808. Vol. 10, p. 123. Son of a farmer from Herefordshire. John at Goswell St Road.

At least three of these were charity placements and two were from the Dissenters' School. That link with the school is part of a pattern. John's children were baptised at Nonconformist churches and he was eventually buried at Bunhill Fields so there can be little doubt of his Nonconformist beliefs. These may have become more pronounced over time, as his son Barak was baptised at Providence Chapel, the home of some particularly 
individual beliefs. ${ }^{11}$ The apprentice records suggest that, at least up until 1804, John worked from Hare Court, Aldersgate Street (where there was a Nonconformist chapel) and may have moved to Goswell Road between 1804 and 1808 . There is also evidence that he was paying land tax of $£ 16 \mathrm{~s}$ $8 \mathrm{~d}$ at Hare Court on Aldersgate Street in the parish of Aldersgate Without between at least 1798 and 1810 (with John Blunt and John Viner on either side). ${ }^{12,13}$ The discrepancy between the 1810 date and living at Goswell Road in 1808 when he took his last apprentice is intriguing.

John was successful and pieces by him are sought after today. The Metropolitan Museum of Art in New York has a pair of his candlesticks, and others, such as those in Figure 2, appear on the market occasionally. ${ }^{14,15}$ In June 2012 a decorative pair of salt cellars from 1820 sold at Christie's, New York. ${ }^{16}$ Silver salvers seem to have been a favourite (he was of course a plateworker). Figure 3 shows a George III salver of his, carrying the arms of Charles Berwick Curtis, that was sold in November 2011. ${ }^{17}$

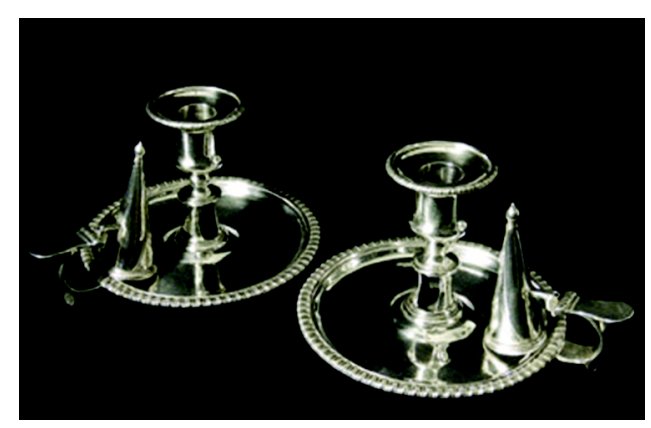

Figure 2. John Mewburn chambersticks (with permission from Robin Silverman).

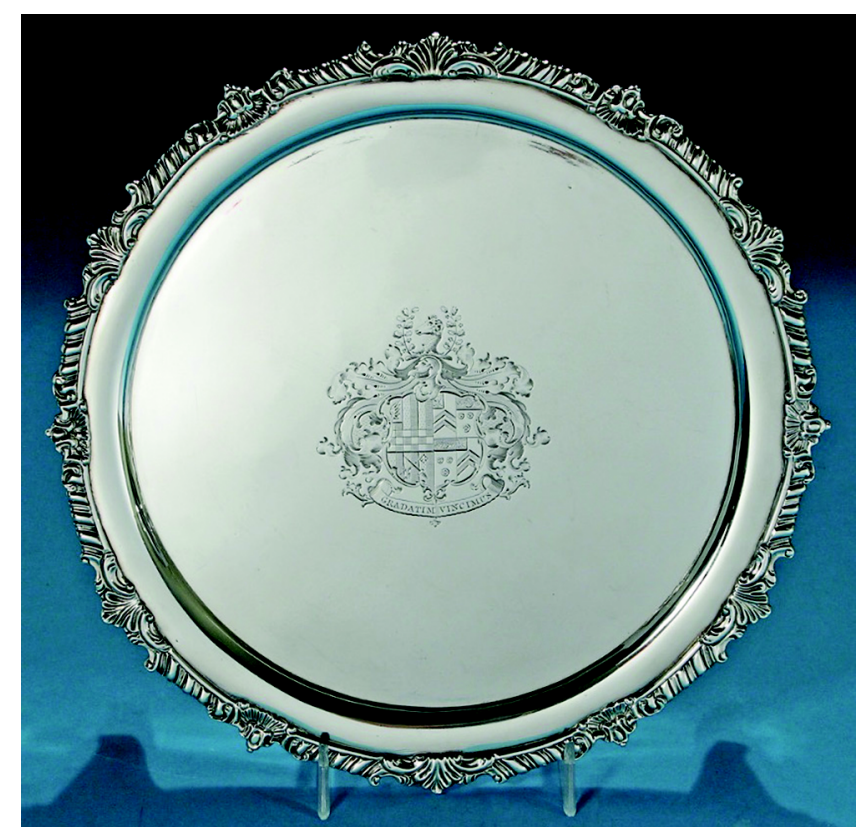

Figure 3. John Mewburn salver of 1810 (photograph by M. Ford Creech, with permission).

John was living on Goswell Road (which continues north from Aldersgate Street) in October 1828 when he made a short will leaving everything in equal measure to each of his children. His son Henry John and John Vinery of Brixton were the executors, while Josh Marston and James Friend acted as witnesses. ${ }^{18}$ No value was indicated. He died in 1830 and was buried on the 2nd of February at Bunhill Fields. ${ }^{19}$ Probate was granted on the 13th of February 1830 (but adds no new information to that in the will). ${ }^{20}$

John had married Susanna Colson on the 4th of November 1786 at St Giles without Cripplegate (John Crouch, presumably his former master, was a witness). ${ }^{21}$ There is no trace of Susanna's death or of any children, but on the 10th of April 1788 at Holborn, John, recorded as a 
widower, was married for a second time to Ann Parsonson of Long Melford, Suffolk. ${ }^{22}$ John Mewburn and Ann Parsonson had six children, as shown in Figure $4 .{ }^{23}$ Two further generations of silversmiths followed before the line petered out.

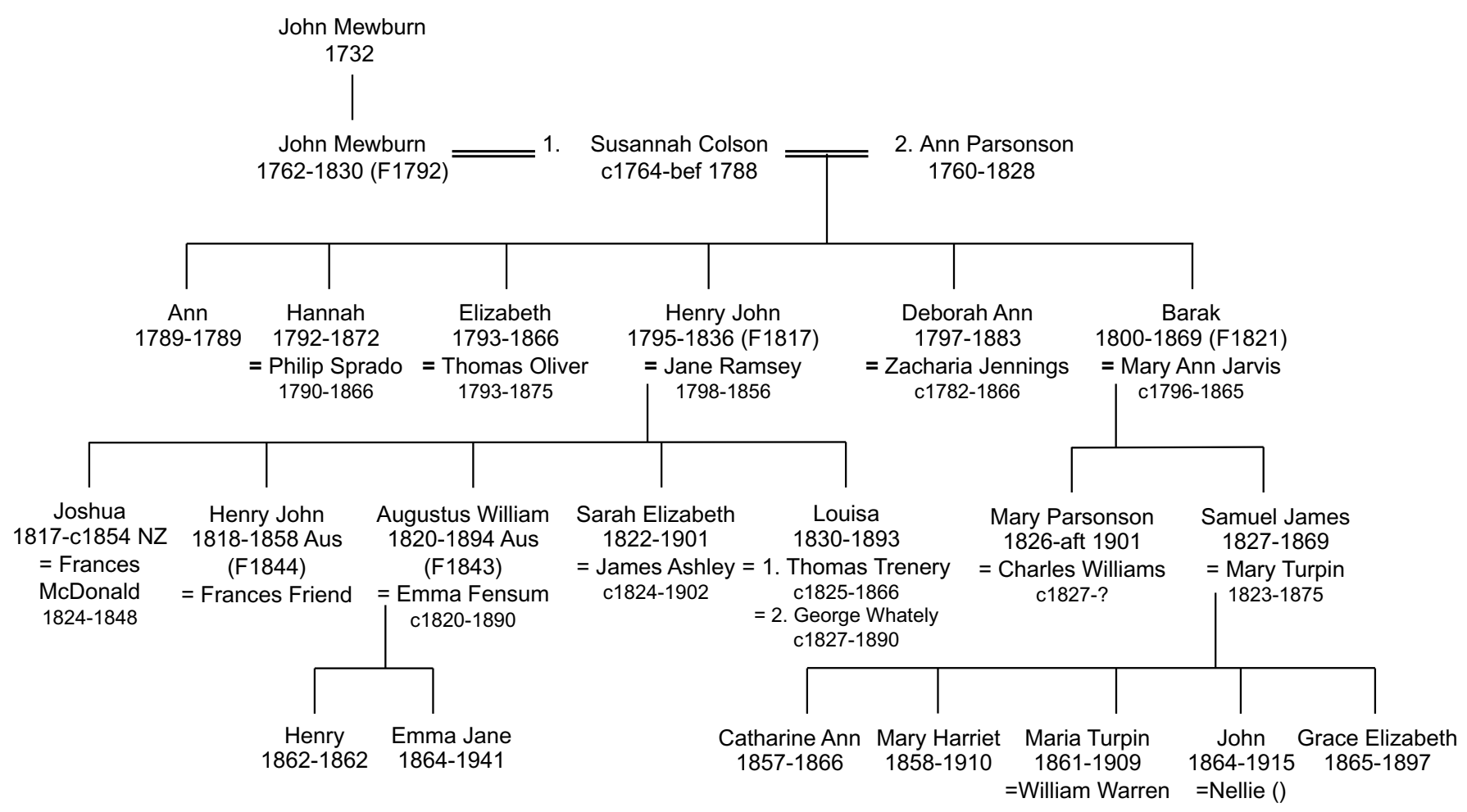

Figure 4. Family tree for John Mewburn, goldsmith (with Freedom dates).

\section{The second generation}

Henry John Mewburn was born on the 6th of November 1795 and baptised on the 26th of February 1796 at St Giles Cripplegate Barbican Independent. ${ }^{24} \mathrm{He}$ is listed in the Freedom Index as becoming a Freeman of the Goldsmiths' Company on the 5th of February $1817 .{ }^{25}$ The full entry in the Freedom Book reads:

\section{7 , February 5th}

Henry John Mewburn Son of John Mewburn was sworn and

made free by Patrimony on the testimony of Richard Sibley Citizen and

Goldsmith and John Viney Citizen and Leather Seller.

Goswell Street Road

Silversmith ${ }^{26}$

(John Viney lived next door to John Mewburn at Hare Court.) Whether Henry John worked much as a silversmith is not known but he described himself as clerk to the Goldsmiths' Company at the time of the baptism of his daughter Sarah in 1822 (he was living then at York Terrace). ${ }^{27}$ In fact he worked at the Assay Office, as minutes from 1817 (the year of his Freedom) show:

14 May $1817 \quad$ At a Court of Assistants

Election of Assay Officers. Vacancy for Fourth Drawer

There were three candidates. Each was interviewed and Henry John elected.

Committee Friday 25 July 1817.

Mr John Henry Mewburn who was lately elected a Drawer in the Assay Office attended the Committee and proposed that his Father Mr John Mewburn of Goswell Street should be his Surety to the Company for the faithful discharge of his duty in the Assay Office and Mr John Mewburn being known to several Gentlemen of the Committee and being approved of, the Security was ordered to be taken accordingly. ${ }^{28}$ 
The Library also has the bond dated the 6 th of August 1817 showing that $£ 100$ was lodged as surety. ${ }^{29}$ In it, Henry John guaranteed to 'carefully draw or cut and mark all such plate as he shall be required to ... to discover if the same be charged with any unnecessary Soder ... forward enough in workmanship ... all pieces be affixed together that are intended to be affixed together and if the same be marked ...'. We know that he progressed from drawer to weigher, the most senior of the working roles in the Assay Office. Forbes describes the role: 'The Weigher was additionally responsible for paying out the weekly wages of the drawers, for the purchase of materials and everyday requirements'. ${ }^{30}$

Henry John married Jane Ramsey on the 9th of November 1815 at Hackney ${ }^{31}$ and they had five children. He died on the 19 th of May 1836 at Kingsland and was buried on the 24th of May at Bunhill Fields. ${ }^{32}$ Minutes of the Court and Committee Book show he had been ill for some time:

\title{
At a Court of Assistants 30 Oct 1835
}

Mr Mewburn had of late been frequently absent from the Hall on account of ill health and was now confined to his house with very little prospect of his again returning to his duties. ${ }^{33}$

(An attached letter from his doctor indicates that he had been suffering from consumption.) His will of the 19th of April 1836 was proved on the 12th of August, leaving $£ 100$ each to his wife and children and $£ 50$ each to his brother Barak and sister Deborah - a total of some $£ 700$ (perhaps a million pounds today). ${ }^{34}$ Jane, though, petitioned the Company for further support:

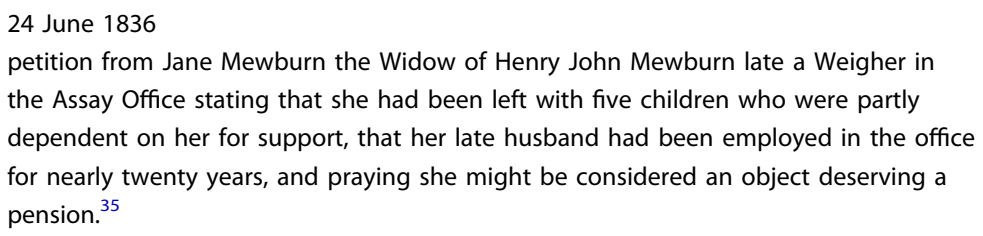

However, she was only partially successful:

\begin{abstract}
it appearing from the statements made by the petitioner who being in attendance was called in and explained her circumstances, that she is fully capable of maintaining herself, submit that she ought not to be admitted as a pensioner on the funds of the Assay Office but that a sum of $£ 30$ be allowed her as a donation .... ${ }^{36}$
\end{abstract}

Barak Mewburn was born on the 7th of June 1800 and baptised on the 1st of September at the Providence Chapel, Titchfield Street. ${ }^{37}$ He too became a silversmith, the third Mewburn to appear in the Black Book, ${ }^{38}$ gaining his Freedom of the Goldsmiths' in 1821.

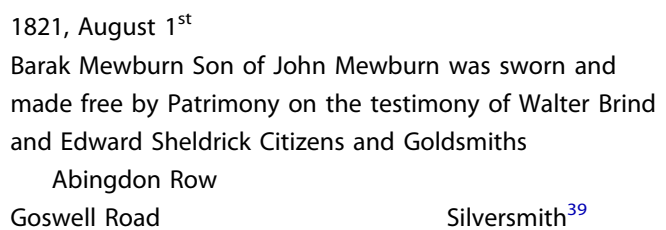

His apprenticeship has gone unrecorded but perhaps this was undertaken with his father. Barak registered marks on three occasions between 1826 and 1831:

Barak Mewburn, Plateworker, 19 Abingdon Row, Goswell Road New mark Removed to Ball Court, Giltspur St New mark

$$
\begin{array}{r}
31 \text { Aug } 1826 \\
1 \text { May } 1830 \\
26 \text { Jan } 1831
\end{array}
$$

His marks are shown in Figure $5 .^{40}$ The first was registered in August 1826 and used during $1827-1828$ and the other registered in May 1830 and used during 1831-1833. 


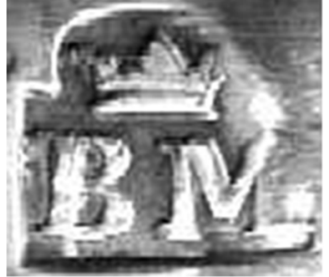

a

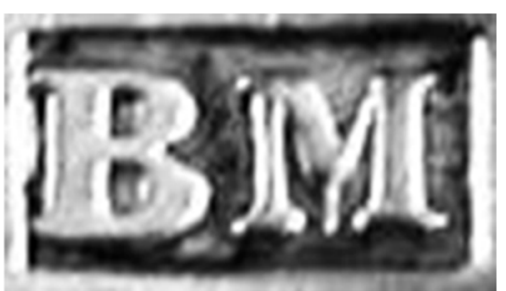

b

Figure 5a and b. Marks used by Barak Mewburn (with permission of www.silvermakersmarks.co.uk).

Grimwade's entry for Barak is as follows:

Son of John Mewburn. Free by patrimony 5 February 1817 as goldsmith. First mark entered as plateworker, 31 August 1826. Address: 19 Abingdon Row,

Goswell Road. Second mark, 1 May 1830. Moved to Ball Court, Giltspur Street, and third mark entered 26 January $1831 .^{41}$

In this case Grimwade made an error over the Freedom, giving the date for Henry John rather than Barak's 1821 date. At the same time, Barak was admitted to Freedom of the City of London. ${ }^{42}$ Barak is also known to have taken on two apprentices, so was clearly operating as a master craftsman from an early point in his career:

- James Friend; 6 Oct 1824; Vol. 10, p. 417. $£ 10$ Charity. Barak at 7 Abingdon Row.

- In Martin Newton; 1 Oct 1834; Vol. 11, p. 80. Father a tinplate worker. Barak at 5 Palmer Street, Stepney.

6 Feb 1839, turned over (having sued out his indenture).

Barak seems to have been another very capable craftsman and his pieces also appear regularly at auction. ${ }^{43,44}$ Barak married Mary Ann Jarvis of Rugeley, Staffordshire on the 25th of July 1824 at Clerkenwell. ${ }^{45}$ They had two children. Although Barak was listed as living at Palmer Street in 1834 when he took his second apprentice, it seems that he still worked at Ball Court as he was listed there on the Electoral Register for $1837 .{ }^{46}$ He does not appear in the registers after that so a decline in his fortunes must have started soon after. Some evidence for this may appear in entries in the London Gazette in 1837 and 1838. The first shows the dissolution of a three-way partnership:

\footnotetext{
... the Partnership heretofore subsisting between us the undersigned, William Newton, Barak Mewburn, and Lewis Chapman, carrying on the trade or business of Metal Flatters, at No. 6, Ball-court, Giltspur-street, in the city of London, was this day dissolved by mutual consent. All debts due to and owing from the said partnership will be received and paid by the said Barak Mewburn and Lewis Chapman, by whom the business will in future be carried on. - Witness our hands this $9^{\text {th }}$ day of September $1837 .{ }^{47}$
}

Why William Newton stepped down is unsaid, but the business continued. The second dissolution between the two remaining partners took place a year later and led apparently to no continuing business, though no detail of the cause is given:

\footnotetext{
... the Partnership heretofore subsisting between us the undersigned, Barak

Mewburn, and Lewis Chapman, carrying on the trade or business of Metal Flatters, at

No. 6, Ball-court, Giltspur-street, in the city of London, was this day dissolved by

mutual consent. - Witness our hands this $9^{\text {th }}$ day of October $1838 .^{48}$
}

Barak and Mary Ann appear in the census of 1841 living at Charles Street, Stepney ${ }^{49}$ but by that time Barak was listed as a corn meter, a civil post carrying responsibility for weights and measures. Barak had retired from silversmithing, apparently because of asthma. By 1851 he and Mary Ann were living at 1 Stratford Terrace, Stepney ${ }^{50}$ (with daughter Mary and son Samuel), with Barak as a deputy corn meter. In 1861 they were at 6 Robinson's Row, Hackney, without any children present and with Barak as a sworn deputy corn meter. ${ }^{51}$ By 1860 , though, Barak had been in straitened circumstances and petitioned the Goldsmiths' Company for a pension: 
1860

Mewburn, Barak aged 60. 6 Robinson Row, Kingsland

Silversmith, formerly in the employment of Messrs Bateman, Bunhill Row, ${ }^{52}$ latterly a

Deputy Corn Meter suffers severely from Asthma and unable to follow his

employment allowed $£ 60$ a year during sickness from the Corn Meters Sick Fund - he

lives in one room has a wife aged 65, a Son a Cripple with a wife and 2 children out of

work.

Petitioner states that his Father was a Liveryman and his Brother was for 20 years a

Drawer in the Assay Office.

Strongly recommended by Mr H. Bateman Liveryman, Mr Wright and Mr Hayworth. ${ }^{53}$

Sad though the tale seems, he was not elected to get any pension. However, we can see how valuable these records can be for the genealogist. The comment about being employed by Bateman is interesting. Perhaps this happened late in his silversmithing after illness prevented him from running his own business? Mary Ann died late in 1865; Barak lived on and died early in $1869 .{ }^{54,55}$ No burial record has been found and he seems not to have left a will.

\section{The third generation}

Henry John and Barak were the only sons in the second generation so the Mewburn line and the continuation of any silversmithing tradition would have been perpetuated through them. Henry John Mewburn had five children and two of his sons did become members of the Goldsmiths' Company, though his eldest, Joshua, did not. Henry John Mewburn the second, and the second son, was born on the 18th of October 1818 and baptised at St Luke, Finsbury on the 24th of January $1819 .{ }^{56} \mathrm{He}$ appears in the Black Book ${ }^{57}$ and is the only other Mewburn for whom we have a record of apprenticeship. He was bound to William Chawner, one of a notable family of silversmiths, on the 5th of December 1832:

1832, Decr $5^{\text {th }}$

Be it Remembered that I Henry John Mewburn Son

of Henry John Mewburn Weigher in the Assay Office Goldsmiths Hall

do bind myself Apprentice to William Chawner of Hosier Lane

Smithfield Silversmith

a Citizen and Goldsmith of London to learn his Art of a Silversmith

_ _ _ for seven years from this day there being paid to my said

Master the sum of $£ 40$

Henry John Mewburn

$3^{\text {rd }}$ July 1839

Turned over by consent to Mary Chawner ${ }^{58}$ of Hosier Lane Silversmith the

Widow of William Chawner late of the same place a Citizen and

Goldsmith of London. ${ }^{59}$

And he was duly made Free of the Company in 1844:

1844, July

Henry John Mewburn Son of Henry John Mewburn was sworn and

made free by Patrimony on the testimony of Barak Mewburn Citizen

and Goldsmith and John Viney Citizen and Leatherseller of London

Rosemary Cottages Silversmith

Shepperton Street Islington. ${ }^{60}$

This second Henry John never registered a mark and took no apprentices; however, he was admitted to Freedom of the City of London. ${ }^{61}$ Henry John married Frances Friend, daughter of jeweller Walter Friend, in $1845 .^{62}$ There is no trace of them having had children. He then followed his elder brother Joshua to Australia. A Mr and Mrs Mewburn travelled steerage on the barque Tam O'Shanter leaving London on the 16th of November and arriving on the 8th of March 1848 at Port Jackson, New South Wales. ${ }^{63}$ He did not pursue the craft of silversmithing and at some point set up as a shopkeeper in Sydney. Figure 6 illustrates a small advertisement from the Sydney Morning Herald in February 1857 that gives a flavour of his business. ${ }^{64}$ Things went badly though, and on the 30th of October 1858 the newspapers, as shown in Figure 7, announced the bankruptcy of the business. ${ }^{65}$ Soon after, his death was announced as having taken place on the 22nd of December 1858 at Pitt Street North, Sydney ${ }^{66}$ His widow, Frances, married a Christopher Bennett on the 1 st of September $1860 .{ }^{67}$ 
Wax Flowers - Prepared wax, 1s 9d per dozen.

Berlin Wools and Fancy Goods, in great variety.

MEWBURN'S Bazaar, Australian House, Market-st.

Figure 6. Henry John's advertising.

INSOLVENCY PROCEEDINGS.

Surrenders.

Henry John Mewburn of Hunter-street, Sydney, fancy

bazaar keeper. Liabilities, $£ 26212 s$ 9d, Assets - value of

personal property, $£ 80$; outstanding debts, $£ 116 \mathrm{~s}$ : total, £81 16s. Deficit, $£ 169$ 16s 9d. Mr Wilson, official assignee.

Figure 7. Failure for Henry John.

Augustus William Mewburn, known as Bill (son of the first Henry John and his wife Jane), was born on the 25th of September 1820 at Finsbury and baptised on the 6th of May 1821 at St Luke. ${ }^{68}$ He was the last of the short dynasty of London silversmithing Mewburns. There is no record of his apprenticeship but he appears in the Black Book ${ }^{69}$ and was made Free of the Worshipful Company of Goldsmiths on the 6 th of December $1843^{70}$ by right of his father Henry John (1796-1836). He was admitted to the Freedom of the City of London on the same day (seven months before his elder brother). ${ }^{71}$

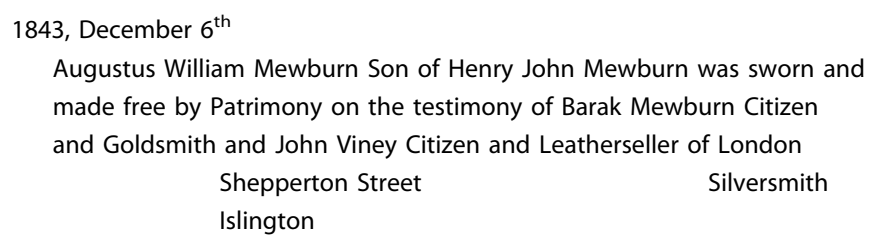

Augustus was still living in London at the time of the 1851 census $^{72}$ and was practising the craft as a journeyman silversmith. Active making was therefore maintained into the third generation. However, he too then emigrated to Australia. The most likely record for the last leg of his journey is that for 'Mr Mewburn 10 Oct 1854, Sydney NSW from Melbourne' aboard the London. ${ }^{73}$ It was an unassisted passage but he travelled steerage, so the family in London by that time clearly had little money to spare. Once in Australia he vanished, but later, as a result of his brother's searching for him to settle probate (Figure 8), ${ }^{74}$ it transpired that he had left Sydney in 1855 for the Turon Diggings. (There had been a gold rush there in 1852, though much of the excitement had cooled by the time he joined in.)

$£ 10$ Reward - Information wanted of JOSHUA
MEWBURN, who in February, 1848, was living with Jose
Vadibia Fabrica de Cohere Caile Dalesibarratillos, Santiago,
Chile, and has not since been heard of. He had lived several
years previous in New Zealand, and was Tatooed all over
the face: known mostly in that country and many islands in
the South Seas, as Moka Wairura, had fair complexion, dark
blue eyes, and black hair, born in London, 1817: was known
to Captain Webster of New Zealand. Also information
wanted of WILLIAM AUGUSTUS MEWBURN youngest
brother to the above, who left Sydney, April 1855, in
company with Louis de Condre for the Turon Diggings, and
has not since been heard of; had dark hair, florid
complexion, partly bald, height 5 feet 10 inches. Anyone
giving satisfactory information to the undersigned of either
of their whereabouts, or producing a satisfactory certificate
of the death of either the abovenamed brothers (if dead) will
receive the above reward. Address HENRY JOHN
MEWBURN, Australian House, Market-street, Sydney.

Figure 8. Search for missing Mewburns: Sydney Morning Herald, 1857.

Bill eventually wrote back to Barak in October 1859 with the news that he had been travelling round the goldfields for four years. The image of a member of the Goldsmiths' Company digging for gold is remarkable! He married Emma Fensum in Sydney in July $1860^{75}$ and established a 
jewellery business there. By 1862 he was living at the seventeen-room Waratah House, Kiama, New South Wales, aiming to run it as a boarding house while also selling watches and jewellery. The boarding house did not work out, ${ }^{76}$ though he continued with the other business. Latterly the Sands Directory shows him as a jeweller living at 14 Paramatta Old Road, Forest Lodge. ${ }^{77}$ Various newspaper snippets indicate that he became a pillar of the community. He died in $1894^{78}$ but appeared still in the Directory for 1895 at 106 Good Hope Street, Paddington where he had died. ${ }^{79}$ Bill and Emma had a son, Henry William, ${ }^{80}$ who died in infancy in $1862,{ }^{81}$ and a daughter Emma Jane in $1864 .^{82}$ She remained unmarried until her death in $1941^{83}$ and is buried at Woronora Cemetery. ${ }^{84}$

Barak Mewburn had two children. Samuel James Mewburn was his only son. He was born on the 20th of July 1827 at Goswell Road, in the parish of St James, Clerkenwell and baptised on the 4th of November. ${ }^{85}$ In 1851 he was still living at home with his parents at 1 Stratford Street, Stepney, and working as a clerk. ${ }^{86}$ He married Mary Elizabeth Turpin on the 10th of June 1856 at Clerkenwell ${ }^{87}$ (she was a 'teacher of town children'). On one of the children's baptismal records in 1858 Samuel was described as a commercial traveller. Nevertheless, in 1860 when Barak petitioned for a pension, Samuel was described as a 'cripple' living with him in a single room. Despite that, by 1861 Samuel and his family were living at 5 Balmes Road, De Beauvoir Town, Hackney and he was styling himself 'gentleman'. ${ }^{88}$ He appeared there in 1861 and 1862 on the Electoral Register ${ }^{89}$ (so a man of some substance, or at least paying significant rent). Samuel died in $1869^{90}$ and at probate was said to have been living at 151 Kingsland Road, with effects under $£ 100,{ }^{91}$ so in the end not the most prosperous of gentlemen.

Samuel and Mary had five children but only one son, John (1864-1915) ${ }^{92,93}$ who was with the family in the 1871 census and then vanished until 1911 when he turned up at Marylebone as an office cleaner. He had apparently been married for the previous fifteen years to Nellie, with no children. His disappearance could suggest emigration, and in 1884 a 20-year-old John Mewburn did ship to Sydney as a crewman working as a servant on the Orient. ${ }^{94}$

And so the line ended with no further practitioners of the silversmiths' craft.

\section{Ancestry of the silversmith John Mewburn}

Entry to London's craft guilds was carefully guarded, so there must be a further question over whether there was anything in John Mewburn's background that might have smoothed the path. There have been Mewburns around London since perhaps the sixteenth century. The earliest baptism was on the 22nd of May 1603 at Aldgate, of a John Meborne, son of a John. ${ }^{95}$ In 1696, on the 31st of January, Christopher Mewburne and his wife Margaret baptised their son William at Holborn. ${ }^{96}$ William may have married a Mary and died in 1740 . Christopher had another son, John, baptised on the 10th of September $1699,{ }^{97}$ who may have married Mary Fellows in $1728 .{ }^{98}$ A third son, Thomas, was baptised at Cripplegate on the 20th of September $1702 .^{99}$

We cannot be sure about kinship links between families in the early eighteenth century, but the timing of births hints at possible descent. Figure 9 offers a hypothetical tree for them. The start of this tree is highly speculative and Christopher's origins are unknown.

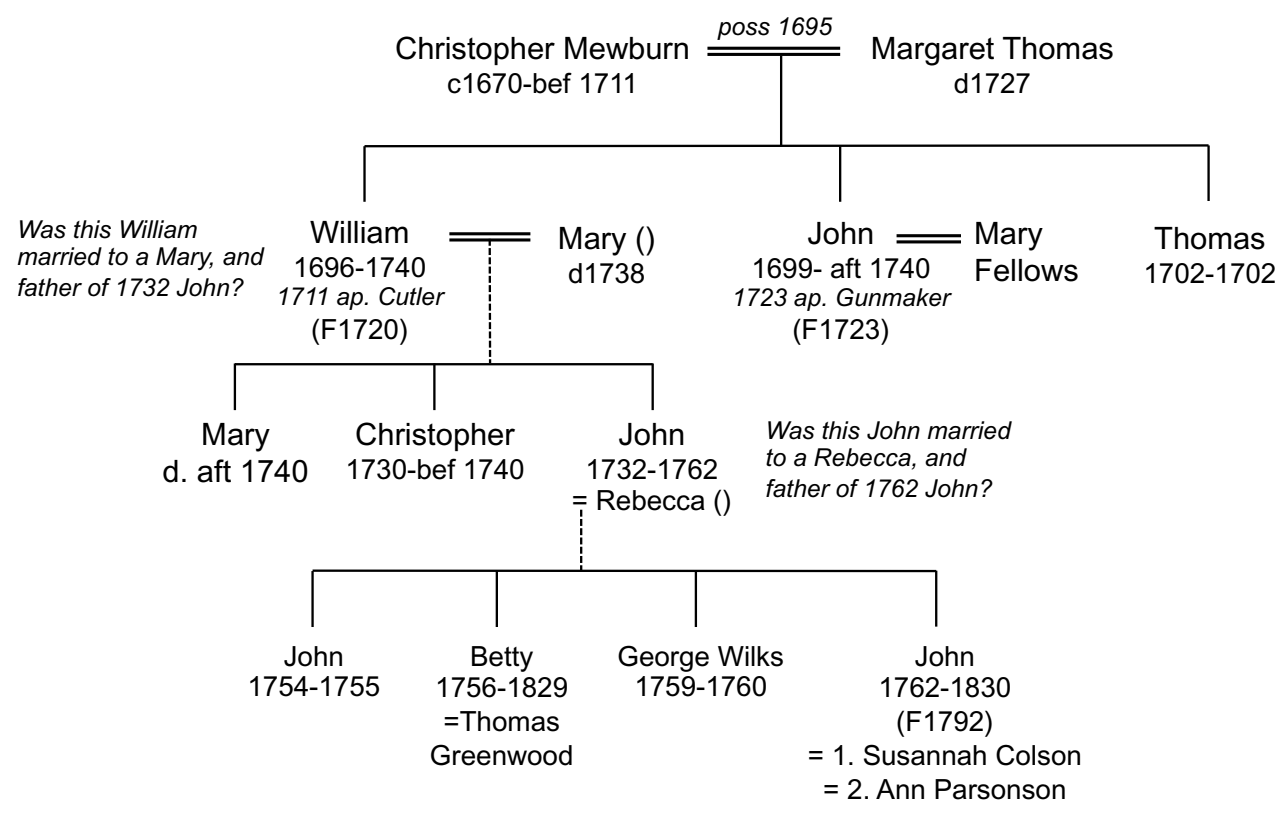

Figure 9. A possible tree for the first London Mewburn craftsmen. 
There is a marriage at the Chapel of the Fleet Prison on the 1st of October 1695 for a Christopher Newborne [sic] - a common misspelling and a Margaret Thomas. ${ }^{100}$ The timing is right but there is little other evidence that this is our couple except that the baptisms for William, John and Thomas indicate that their mother was named Margaret. The next intriguing scrap comes in the form of an indenture for William in 1711. It tells us that 'William Mewburn son of Christopher Mewburn late of the parish of St Andrews Holborn in the County of Middx founder doth put himself Apprentice to William Child Citizen and Cutler' and later that it was 'put out by Charity School of St Andrew Holborn'. ${ }^{101}$ So his father had died, leaving his children poverty-stricken. However, since his father had been a founder, i.e. a member of the Guild of Founders, the Guildry and the parish rallied round to provide an apprenticeship, again in a metal trade. William died in 1740 and made a will that year. ${ }^{102}$ He described himself as of 'Whitefriars Precinct London Sword Cutler'. He left a quantity of jewellery to his daughter Mary, the jewellery being at his lodgings in the house of John Mewburn at Whitefriars (presumably his brother). There is another indenture for John Mewburn, son of Christopher the founder. He was apprenticed to Thomas Jones, gunmaker. ${ }^{103}$ John married Mary Fellows in $1728^{104}$ but there are no records of any children. William (1696), however, was of a good age to be father to Christopher (born in 1730) and John (born in 1732), and no other William is known from London records to provide an alternative.

So far our snippets of evidence suggest linkage among these early principal characters. Subsequent records provide births of four Mewburns between 1754 and 1762 to a John and Rebecca. We cannot be certain that this was John born in 1732, even though the timing is good. The apprenticeship record for his son states that John was a mariner rather than any form of metalworker. However, the rarity of the Mewburns and the lack of any other candidate encourages the thought that John, born in 1732, was the father of John born in 1762, and that this is the point of origin for the London silversmiths. These are hypotheses for earlier ancestry and further work is envisaged to test them.

\section{Conclusion}

It has proved possible, using an array of records and systematic genealogical methods and analysis, to determine a history of the line of Mewburn silversmiths, and their eventual disappearance. It has answered the question: who were these Mewburns? For the first time a substantive account of the lives of the silversmiths John and Barak Mewburn is presented. This will be of value to researchers into the history of the silversmithing craft and of interest to those who wish to understand more about the lives of eighteenth- and nineteenthcentury craftsmen. Key to the successful unravelling of that account are the records held at the library of the Goldsmiths' Company in London and this article has demonstrated, through examples and references, the value that these records can offer to the genealogist and family historian.

What else might we glean from a study such as this? John Mewburn was a Nonconformist, so there may be an opportunity to examine that aspect of his life in greater detail as an example of the influence of these beliefs in the crafts and in guild affairs.

It is possible to suggest that these lives illustrate the old saw of riches to rags in three generations. Whether that notion has any real meaning must be doubted, but the article does perhaps show how a spark of genius such as the one that touched John Mewburn cannot readily be sustained in an unsupportive and harsh social milieu. It will be interesting to see whether this thought can be used to trigger wider studies across a range of family histories into the behaviour and dynamics of social structures and notions of continuity and sustainable capability within them. Can we identify factors that enable families and social groups to extend their existence over substantial periods? By asking these kinds of questions it may be that what on the surface is a relatively conventional study of family history can move our thinking in a different direction.

\section{Citation information}

Cite this article as: Macdonald, lan G. (2017) Mewburn: London silversmiths. Journal of Genealogy and Family History. 1(1). http://dx.doi.org/10.24240/23992964.2017.030101

\section{References}

1. Baptisms (PR) England. St Andrew, Holborn, London. 06 Feb 1762. MEABURN, John. Collection: www.ancestry.com/.

2. Goldsmiths' Company Library, Foster Lane, London. https://www.thegoldsmiths.co. uk/craft/library-research/about-visit/.

3. Goldsmiths' Company. Apprenticeship and Freedom Index, 1578- 'The Black Book'. London: Goldsmiths' Library.

4. Goldsmiths' Company. Apprentice book, 1763-1779, Vol. 8, p. 302. London: Goldsmiths' Library.

5. Grimwade, Arthur. (1990) London goldsmiths - 1697-1837 - their marks and lives. $3^{\text {rd }}$ rev. London: Faber \& Faber, p. 596.

6. Today this runs off London Wall though formerly was the first part of that road. It lies next to St Giles Cripplegate where the children were all baptised.

7. If an apprentice became a freeman, this would be recorded in a Freedom book. These begin in 1692
8. Grimwade, Arthur. (1990) London goldsmiths - 1697-1837 - their marks and lives. $3^{\text {rd }}$ rev. London: Faber \& Faber, entries 1528, 1529, 3659, p. 207.

9. Ciceri, Giovanni. (2011) British hallmarks - a cycle at a time (I) London hallmarks: 1776-1795 (XVI Cycle). Association of Small Collectors of Antique Silver website. http://www.ascasonline.org/articoloGENNA142.html.

10. Goldsmiths' Company. A List of the Wardens, Assistants and Livery of the Worshipful Company of Goldsmiths, London, 1829. Goldsmiths' Hall Library no. 3215: B39.

11. 'In Little Titchfield-street is a chapel (called Providence chapel) belonging to a congregation who profess the doctrines of the late Mr. Whitfield, and style themselves Independents. Their minister is a man who was a coal-heaver, and for some whimsical reasons changed his name from Hunt to Huntington. He is author of a great variety of tracts, which are in much esteem among his followers. Some of them are of a very singular cast, especially one in which he illustrates the doctrine of a particular providence in a very improper and mistaken way.' http:// www.british-history.ac.uk/london-environs/vol3/pp242-279.

12. Tax records. (1798) Aldersgate Within, City of London. MEWBURN, John. MS 11316/ Vol. 297. Collection: London, Land Tax Records, 1692-1932. www.ancestry.com/.

13. Tax records. (1810) Aldersgate Without, City of London. MEWBURN, John. MS 11316/ Vol. 333. Collection: London, Land Tax Records, 1692-1932. www.ancestry.com/. 
14. Metropolitan Museum of Art. (2006) Chamber candlestick (one of a pair) John Mewburn. http://www.metmuseum.org/collection/the-collection-online/search/ 232346

15. Silverman Antiques. English silver chambersticks. Kensington Church Street Antique Dealers Association website. http://www.antiques-london.com/index.pl?isa= Metadot::SystemApp::AntiqueSearch;op=detail;id=96420.

16. Christie's. A pair of George IV silver salt cellars. Mark of John Mewburn, London, 1820. Sale 2645, New York, 21 June 2014. http://www.christies.com/lotfinder/lot/apair-of-george-iv-silver-salt-5579002-details.aspx.

17. Creech, M. Ford. (2011) 'George III Silver Salver, John Mewburn, London 1810'. M. Ford Creech Antiques \& Fine Arts website. http://www.mfordcreech.com/George_II_ Silver_Salver_John_Mewburn_London_1810_Arms_Curtis.htm.

18. There appears to have been a close link to the Friend family. Son Barak took on a James Friend as apprentice in 1824 and grandson Henry John married a Frances Friend in 1845 .

19. Burials (PR) England. London, Middlesex. 02 February 1830. MEWBURN, John. Class RG4; Piece 3998. Collection: England \& Wales, Non-Conformist and Non-Parochial Registers, 1567-1970. www.ancestry.com/.

20. Testamentary records England. Prerogative Court of Canterbury. 13 February 1830 MEWBURN, John. PROB 11/1767/44. Kew: The National Archives.

21. Marriages (PR) England. St Giles without Cripplegate, City of London. 04 Novembe 1786. MEWBURN, John and COLSON, Susanna. P69/GIS/A/01/Ms 6421/2. Collection: London, England, Marriages and Banns, 1754-1921. www.ancestry.com/.

22. Marriages (PR) England. Holborn St Sepulchre, City of London. 10 April 1788 MEWBURN, John and PARSONSON, Ann. P69/SEP/A/01/Ms 7222/4. Collection: London, England, Marriages and Banns, 1754-1921. www.ancestry.com/.

23. A substantial family tree for a majority of Mewburns is hosted by the Guild of OneName Studies at www.mewburn.one-name.net.

24. Baptisms index (PR) England. St Giles Cripplegate Barbican Independent, London. 26 February 1796. MEWBURN, Henry John. Collection: England Births and Christenings, 1538-1975. https://familysearch.org/pal:/MM9.1.1/JMVX-WLW.

25. Goldsmiths' Company. Apprenticeship and Freedom Index, 1578- 'The Black Book'. London: Goldsmiths' Library.

26. Goldsmiths' Company. 'Freemen by servitude and patrimony', Freedom Book, 18101840, Vol 4. 05 February 1817. MEWBURN, Henry John. London: Goldsmiths' Library

27. Baptisms (PR) England. Finsbury, Islington. 04 August 1822. MEWBURN, Sarah Elizabeth. Collection: London, England, Births and Baptisms, 1813-1906. www. ancestry.com/.

28. Goldsmiths' Company. Assay Office Court and Committee Book, 1813-1821. p. 215 and p. 225. London: Goldsmiths' Library.

29. In terms of labour value that was equivalent to over $£ 70,000$ today - a sizeable surety.

30. Forbes, J.S. (1988) Hallmark. A history of the London Assay Office. London: The Goldsmiths' Company, p. 195.

31. Marriages (PR) England. Hackney, Middlesex. p. 173, no. 518. 09 November 1815 MEWBURN, Henry John and RAMSEY, Jane. Collection: Marriages and Banns, London, England, 1754-1921. www.ancestry.com/

32. Burials index England. Bunhill Fields, City of London. 24 May 1836. MEWBURN, Henry John. National Burial Index. $3^{\text {rd }}$ ed. Manchester: Federation of Family History Societies, 2010

33. Goldsmiths' Company. Assay Office Court and Committee Book, 1813-1821. p. 228 London: Goldsmiths' Library.

34. Testamentary records England. Principal Registry, London. 12 August 1836 MEWBURN, Henry John. Collection: England \& Wales National Probate Calendar (Index of Wills and Administrations), 1861-1941.

35. Goldsmiths' Company. Assay Office Court and Committee Book, 1813-1821. pp. 261263. London: Goldsmiths' Library.

36. Goldsmiths' Company. Assay Office Court and Committee Book, 1813-1821. pp. 261263. London: Goldsmiths' Library.

37. Baptisms index (PR) England. Providence Chapel, Titchfield Street, London. 01 September 1800. MEWBURN, Barak. Collection: England Births and Christenings, 1538-1975. https://familysearch.org/pal:/MM9.1.1/JMVF-7TL.

38. Goldsmiths' Company. Apprenticeship and Freedom Index, 1578- 'The Black Book' London: Goldsmiths' Library.

39. Goldsmiths' Company. 'Freemen by servitude and patrimony', Freedom Book, 18101840, Vol. 4. 01 August 1821. MEWBURN, Barak. London: Goldsmiths' Library.

40. Osbourn, Phil. 'Barak Mewburn'. Makers' marks on British \& Irish silver. http://www. silvermakersmarks.co.uk/Makers/London-B.html.

41. Grimwade, Arthur G. (1990) London goldsmiths - 1697-1837 - their marks and lives. $3^{\text {rd }}$ rev. London: Faber \& Faber, p. 596.
42. Freedom Admission Papers. City of London. Jun-Dec 1821. MEWBURN, Barak Collection: London, England, Freedom of the City Admission Papers, 1681-1925. www.ancestry.com/.

43. Sotheby's. A George IV silver salver, Barak Mewburn, London, 1828. Arts of Europe, 15 May 2014, London. http://www.sothebys.com/en/auctions/ecatalogue/2014/artseurope-l14301/lot.389.html.

44. Bonhams. A George IV silver salver by Barak Mewburn London 1827. The Chester sale, 12 June 2012. http://www.bonhams.com/auctions/19891/lot/248/.

45. Marriages (PR) England. Clerkenwell, Middlesex. p. 257, no. 770. 04 Septembe 1824. MEWBURN, Barak and JARVIS, Mary Ann. Collection: Marriages and Banns, London, England, 1754-1921. www.ancestry.com/.

46. Electoral listings. (1837) Farringdon Without, London. MEWBURN, Barak. p. 400. Collection: London, England, Electoral Registers, 1832-1965. www.ancestry.com/.

47. Notices. (1837) London Gazette, 12 September, Issue 19540, p. 2408. https://www. thegazette.co.uk/London/issue/19540/page/2408.

48. Notices. (1838) London Gazette, 12 October, Issue 19663, p. 2172. https://www. thegazette.co.uk/London/issue/19663/page/2172.

49. Census. 1841. England. Stepney, Middlesex. ED 20, p. 13. 06 June 1841. MEWBURN, Barak. www.ancestry.com/.

50. Census. 1851. England. Stepney, Middlesex. ED 1, p. 54. 30 March 1851. MEWBURN, Barak. www.ancestry.com/.

51. Census. 1861. England. Hackney St John, Middlesex. ED 6, p. 20. 07 April 1861. MEWBURN, Barak. www.ancestry.com/.

52. 'Having first traded alone, William Bateman was joined by Daniel Ball junior at 108 Bunhill Row, Chiswell St [31.12.1839] where they are listed in 1840 as goldsmiths. They dissolved their partnership on $11^{\text {th }}$ April 1843.' John Culme, The Directory of Gold \& Silversmiths, Jewellers \& Allied Traders 1838-1914 from the London Assay Office Registers. Woodbridge: Antique Collectors Club, 1987, p. 34

53. Goldsmiths' Company. Petitioners Males, no. 1. 1860. London: Goldsmiths' Library.

54. Deaths index (SR) England. Hackney, London. Oct-Dec 1865. MEWBURN, Mary Ann. Vol 1b, p. 276. www.freebmd.org/.

55. Deaths index (SR) England. Pancras, London. Jan-Mar 1869. MEWBURN, Barak. Vol 1b, p. 140. www.freebmd.org/.

56. Baptisms (PR) England. St Luke, Finsbury, London. 24 January 1819. NEWBURN [sic], Henry John. Collection: London, England, Births and Baptisms, 1813-1906. www. ancestry.com/.

57. Goldsmiths' Company. Apprenticeship and Freedom Index, 1578- 'The Black Book'. London: Goldsmiths' Library.

58. The widow of a member of the Goldsmiths' Company could become free of the Company in her own right, and register her mark, on the death of her husband.

59. Goldsmiths' Company. Apprentice Book, 1828-1897, Vol. 11, p. 56. London: Goldsmiths' Library.

60. Goldsmiths' Company. 'Freemen by servitude and patrimony', Freedom Book, 18411874, Vol 5. July 1844. MEWBURN, Henry John. London: Goldsmiths' Library.

61. Freedom Admission Papers. City of London. 03 July 1844. MEWBURN, Henry John. Collection: London, England, Freedom of the City Admission Papers, 1681-1925. www.ancestry.com/.

62. Marriages (PR) England. Islington, Middlesex. 21 June 1845. St Mary, p. 201, no. 401 MEWBURN, Henry John and FRIEND, Frances. Collection: Marriages and Banns, London, England, 1754-1921. www.ancestry.co.uk/.

63. Travel records. Port Jackson, New South Wales. 08 March 1848. MEWBURN, Mr. Collection: New South Wales, Australia, Unassisted Immigrant Passenger Lists, 1826-1922. www.ancestry.co.uk/

64. Advertising. (1857) Sydney Morning Herald. 28 February. no. 5848 - Vol. 38, p. 6. http://trove.nla.gov.au/.

65. Insolvency proceedings. (1858) Maitland Mercury and Hunter River General Advertiser. New South Wales. 28 October. p. 2. http://trove.nla.gov.au/.

66. Death announcements. (1858) Sydney Morning Herald. 24 December. no. $6412-$ Vol. 39, p. 1. http://trove.nla.gov.au/.

67. Marriages index Australia. Sydney, New South Wales. 1860. BENNETT, Christopher and MEWBURN, Frances. https://familyhistory.bdm.nsw.gov.au/lifelink/familyhis tory/search/result?3.

68. Baptisms index (PR) England. St Luke, Finsbury, London. 06 May 1821. MEWBURN Augustus William. Collection: England Births and Christenings, 1538-1975. https:// familysearch.org/pal:/MM9.1.1/NP7P-XJL.

69. Goldsmiths' Company. Apprenticeship and Freedom Index, 1578- 'The Black Book'. London: Goldsmiths' Library.

70. Goldsmiths' Company. 'Freemen by servitude and patrimony', Freedom Book, $1841-$ 1874, Vol 5. 06 December 1843. MEWBURN, Augustus William. London: Goldsmiths' Library. 
71. Freedom Admission Papers. City of London. 06 December 1843. MEWBURN, Augustus William. Collection: London, England, Freedom of the City Admission Papers, 1681-1925. www.ancestry.com/.

72. Census. 1851. England. Islington, Middlesex. ED 27, p. 40. 30 March 1851 MEWBURN, Augustus W. www.ancestry.com/.

73. Travel records. Australia. Sydney to Melbourne. 10 October 1854. MEWBURN, Mr. London. Collection: New South Wales, Australia, Unassisted Immigrant Passenger Lists, 1826-1922. www.ancestry.co.uk/.

74. Advertising. (1857) Sydney Morning Herald. 28 February. no. 5848 - Vol. 38, p. 1 http://trove.nla.gov.au/.

75. Marriages index Australia. Sydney, New South Wales. 1860. MEWBURN, Augustus William and FENSUM, Emma. Collection: Australia Marriage Index, 1788-1950. www.ancestry.com/.

76. Original correspondence. (1865) Kiama Independent and Shoalhaven Advertiser. New South Wales. 16 March. p. 2. http://trove.nla.gov.au/

77. Directories. Australia. (1858-1933) Forest Lodge, New South Wales. 1890 MEWBURN, Augustus W. p. 778. Collection: Sands Directories: Sydney and New South Wales, Australia, 1858-1933. www.ancestry.com/.

78. Deaths index Australia. Paddington, New South Wales. 1894. MEWBURN, Augustus William. Reg. 10360. Collection: Australia Death Index, 1787-1985. www.ancestry. $\mathrm{com} /$.

79. Directories. Australia. (1858-1933) Paddington, New South Wales. 1890. MEWBURN, A. W. p. 685. Collection: Sands Directories: Sydney and New South Wales, Australia, 1858-1933. www.ancestry.com/.

80. Births index Australia. Sydney, New South Wales. 1862. MEWBURN, Henry W. Reg 397. Collection: Australia Birth Index, 1788-1922. www.ancestry.com/

81. Deaths index Australia. Sydney, New South Wales. 1862. MEWBURN, Henry W. Reg 432. Collection: Australia Death Index, 1787-1985. www.ancestry.com/.

82. Births index Australia. Kiama, New South Wales. 1864. MEWBURN, Emma J. Reg 9349. Collection: Australia Birth Index, 1788-1922. www.ancestry.com/.

83. Deaths index Australia. Kiama, New South Wales. 1941. MEWBURN, Emma Jane Reg. 14790. Collection: Australia Death Index, 1787-1985. www.ancestry.com/.

84. Burials index Australia. Sutherland, New South Wales. 1941. MEWBURN, Emma Jane. Woronora Cemetery. Collection: Australia Cemetery Index, 1808-2007. www.ances try.com/.

85. Baptisms (PR) England. St James, Clerkenwell, London. 04 November 1827. NEWBURN [sic], Samuel James. Collection: London, England, Births and Baptisms, 1813-1906. www.ancestry.com/.

86. Census. 1851. England. Stepney, Middlesex. ED 01, p. 55. 30 March 1851 MEWBURN, Saml. www.ancestry.com/

87. Marriages (PR) England. Clerkenwell, Middlesex. p. 200, no. 399. 10 June 1856. MEWBURN, Samuel James, and TURPIN, Mary Elizabeth. Collection: London, England, Marriages and Banns, 1754-1921. www.ancestry.com/

88. Census. 1861. England. Hackney, Middlesex. ED 17, p. 52. 07 April 1861. NEWBORN [sic], Saml James. www.ancestry.com/.
89. Electoral listings. St John Hackney, Tower Hamlets. Newburn [sic], Samuel James. p. 302. Collection: London, England, Electoral Registers, 1832-1965. www.ancestry. co.uk/.

90. Deaths index (SR) England. Shoreditch, London. Jan-Mar 1869. MEWBURN, Samue James. Vol. 1C, p. 142. www.freebmd.org/.

91. Testamentary records England. London. 15 June 1869. MEWBURN, Samuel James, Collection: England \& Wales, National Probate Calendar (Index of Wills and Administrations), 1858-1966. www.ancestry.com/.

92. Births index (SR) England. Hackney, London. Jan-Mar 1864. Vol. 1b, p. 373 MEWBURN, John. www.freebmd.org.uk/.

93. Deaths index (SR) England. St Pancras, London. Jul-Sep 1915. MEWBURN, John. Vol, 1b, p. 80. www.freebmd.org/.

94. Travel records. Australia. 18 January 1884. MEWBURN, John. Collection: New South Wales, Australia, Unassisted Immigrant passenger Lists, 1826-1922. www.ancestry. co.uk/.

95. Baptisms index (PR) England. St Botolph Without Aldgate, London. 22 May 1603. MEBORNE, John. Source film no. 370924-28. Collection: England Births and Christenings, 1538-1975. https://familysearch.org/pal:/MM9.1.1/NL26-3WR.

96. Baptisms index (PR) England. Holborn, London. 31 January 1696. MEWBURNE, William. Source film no. 374351-2. Collection: England Births and Christenings, 1538-1975. https://familysearch.org/pal:/MM9.1.1/NLLW-59K.

97. Baptisms index (PR) England. St Sepulchre, London. 10 September 1699 MEWBURN, John. Source film no. 374999. Collection: England Births and Christenings, 1538-1975. https://familysearch.org/pal:/MM9.1.1/NLN3-6R7.

98. Marriages (PR) England. St Benet Paul's Wharf, London. 11 February 1728 MEWBOURN, John and FELLOWS, Mary. Ref. P69/BEN3/A/003/MS05718, Item 002. Collection: London, England, Baptisms, Marriages and Burials, 1538-1812. www.ancestry.co.uk/.

99. Baptisms index (PR) England. St Giles Cripplegate, London. 11 September 1702. MEWBORN, Tho. Source film no. 380204. Collection: England Births and Christenings, 1538-1975. https://familysearch.org/pal:/MM9.1.1/JW7L-9LR.

100. Marriages (PR) England. Fleet Prison, London. 01 October 1695. NEWBORNE [sic], Christopher and TOMAS, Margret. Class: RG7; Piece: 833. Collection: London, England, Clandestine Marriage and Baptism Registers, 1667-1754. www.ancestry. co.uk/.

101. Apprenticeship indentures. 13 October 1711. MEWBORNE, William. Collection: London, England, Freedom of the City Admission Papers, 1681-1925. www.ancestry.com/.

102. Testamentary records England. London. 1740. MEWBOURN, William. Collection: London, England, Wills and Probate, 1507-1858. www.ancestry.com/.

103. Freedom Admission Papers. City of London. 13 February 1723. MEWBURN, John. Collection: London, England, Freedom of the City Admission Papers, 1681-1925. www.ancestry.com/.

104. Marriages (PR) England. City of London. 11 February 1728. MEWBOURN, John and FELLOWS, Mary. Ref. P69/BEN3/A/003/MS05718. Collection: Baptisms, Marriages and Burials, 1538-1812, London. www.ancestry.com/.

\section{ABOUT THE AUTHOR}

Dr lan G. Macdonald, MSc (Genealogical Studies), C.Eng, CITP, FBCS, is a zoologist, explorer, information engineer, quality award assessor and latterly genealogist. Ian is a tutor for the University of Strathclyde's online postgraduate genealogy courses and chronicler of the Mewburn family. He is Chairman of the Register of Qualified Genealogists.

Email: iangmacdonald@qualifiedgenealogists.org 